\title{
National Images of Countries \\ in Intercultural Interaction \\ of World Civilizations in Modern Period
}

\author{
Irina Borisenko* and Gyulmira Grigoryeva \\ South-Russia State University of Economics and Services \\ 147 Shevchenko, Shakhty, Rostov region, 346500, Russia
}

Received 24.01.2013, received in revised form 02.02.2013, accepted 28.12.2014

The formation of the national identity is determined by the process of comparing "yourself" with "the other". The feeling of the national identity is fixing the differences "our-strangers", "ours-not ours". When the ethnic culture is formed there is an intensive process of self-reflection, self-identification, "the image of yourself" is made up in relation to the "images" of other people, countries and cultures.

Since ancient times the human consciousness has a particular relevance to the problem of forming the image of someone's people and images of other people.

This article analyzes the problem mentioned above. It examines the national images of the system of intercultural interaction of world civilizations in the modern period. The authors find out that a high degree of cultural differences and peculiarities of religious traditions, secular political divisions and military conflicts between Russia and the West contributed to the formation of various barriers that hinder the achievement of an adequate mutual perception and understanding of two civilizations. In modern times for a more complete and clear mutual understanding of national images the national problem of overcoming the various kinds of communication barriers between the West and Russia is being actualized. The basic techniques of forming "a national image" are advertising and public relations.

Keywords: national image, national identity, intercultural interaction, image making.

DOI: 10.17516/1997-1370-2015-8-9-1955-1964.

Research area: culture studies, philosophy.

\section{Introduction}

Analysis of the problem of identity of national culture is closely linked with the definition of the place and role of Russia in the world culture. The formation of the national identity is due to the process of comparing "yourself" with "other". The sense of your national identity is the fixation of distinguishing "ours - strangers"
When the ethnic culture itself is formed, then there is an intensive process of self-reflection, self-identification; "the image of yourself" is created in relation to the "images" of other people, countries and cultures. Even in ancient times in the European consciousness there was a problem of geographic and cultural identity and differentiation of people and countries. Ancient

(C) Siberian Federal University. All rights reserved

* Corresponding author E-mail address: borisenkoiv@mail.ru, shevchenko76@bk.ru 
Greeks called all those who did not speak their language "barbarians". As the historian Jaspers C. says: "The Greeks laid the foundations of the Western world, and made sure that the world exists only insofar as they constantly direct their gaze to the East, which is in the disengagement with it, understanding it and pulling away from it, taking over from it some certain characteristics and processing them, fighting with it, and in this struggle the power goes alternately from one side to another". Thus, since ancient times human consciousness has had a special attitude towards the problem of forming the image of one's people and images of the others.

\section{Review of literature}

The image of Russia as it has been realized and historically changed in Russia is one of the key problems of contemporary thoughts of philosophers, political scientists and historians. O.D. Volkogonova has done a fundamental research on the perception of Russia in the philosophy of the Russians living abroad. The problem of how Russia and the Russians are perceived abroad are examined by L.V. Belgorodskaya, C.A. Belkovsky, M.G Nosov, L.S. Ruban, O. V. Ryabov, O.M. Zdravomyslova. How adequate are the myths about Russia, what are the barriers to intercultural mutual understanding between Russia and the West, all these difficult questions are answered in the works of V.F. Shapovalov.

L.V. Belgorodskaya examines the images of Russians in the Anglo-American encyclopedias. B.I. Koval and L.D. Dyakova try to show how the image of Russia is formed in the consciousness of the Latin American people.

Alexander Yakovenko, S. Belgorodski, S. Mironova, J. Ivanov, Dmitry Rogozin, R. Abdulatipov, M. Sorokin discuss the problem of Russia"s international image and how to make it better.
For a deeper comprehension of the global processes that change the "face" of our society and its inner essence, it is necessary to refer to the modern scientific papers by E.A. Bagramov, E.Y. Batalov and K. Eckstein.

The problem of how foreigners are perceived in Russia is analyzed by I.N. Beloborodova, Y.S. Borisov, A.V. Golubev, A.N. Sakharov, T.V. Kireev, V.G. Kismereshkin, G.G. Pocheptsov, L.S. Mamut and S.V. Obolenskaya.

How to create a positive image of Russia? The modern image of Russia is of a great interest of such scientists as A.K. Vafa, B. Dubin, E.V.Dmitrov,D.N.Zamyatin,O.M.Zdravomyslova I. Semenenko, I.V. Sledzevski and E.P. Chelyshev.

E.A. Galum, and B.S. Yerasov indicate that serious scientific study of the image forming of Russia are necessary. Hence we get the specific proposals of the following scientists: B. Kononeko, N.V. Laidinen, V. Mikhailov, Alexander Yakovenko, I.L. Rozhkov, E.N. Kartseva, A.P. Nazaretyan. According to G.D. Gachev "the development of problems of national images of the world could have a direct practical importance for understanding among people".

\section{Historical background}

Our own image in Russian culture and the image of the others (the other country and its people) is an instrument of self-knowledge, the method of creation of "your own image", comparing "images" with the dynamics of the Russian cultural process and the evolution of ideas about others and about yourself.

In the history of national cultural philosophical ideas, A.N. Erygin identified the following conceptual ideas about the definition of the place and role of Russia in the global cultural context:

1) The idea of exclusivity of Russia in the world history and culture; 
2) The idea of Russia as the East;

3) The idea of Russia as the West;

4) The idea of Russia as a special Slavic civilization;

5) The idea of Russia as a Eurasian country different from the East and the West;

6) The idea of Russian specificity which is expressed in a combination of Eastern and Western characteristics or in the swinging between the East and the West;

7) The idea of Russian identity in the Christian world;

8) The idea of universality of the Russian spirit;

9) The idea of Russia as a "third force" and in this case as a synthesis of the East and the West;

10) The idea of Russia as a necessary element of global fusion (Erygin A.N. 1998).

Since the times of Peter I the West has been one of the important factors of national identity in Russia. "Looking in the West like in a mirror, comparing itself to it, Russia was trying to grasp its essence, to define its place in the world and its mission in history. As a result of comparing our country with its western neighbors some people came to the conclusion that Russia has its own way of development and we should not change it. Other people, while noting its backwardness of Europe and America, offered compatriots to ask "Germans" to train us and try to follow their own way". (Batalov E.Y. 2003) As the political scientist E.Y. Batalov says, Russia has never been a factor in the political or civilizational identity for the West. The West has always had a sense of superiority in relation to Russia. This can be explained by the influence of Eurocentric ideological doctrine, specific to Western consciousness. It is interesting to note that in times of war and conflicts the West was afraid of Russia. "But at the same time, says Batalov, they have never seen Russia as an authoritative mentor, and even more - a model to follow. So without much emotion the West concerned to Russia's opinion of itself. And it also made Russia offended and irritated" (Batalov E.Y. 2003).

Historically Russia has formed an ambivalent attitude toward the West. Russia perceived the West as an entity different from it and at the same time as the multi-sided, internally differentiated world. This was reflected in the philosophical essays, works of art culture of the Russian thinkers and artists. Why does the West play such a crucial role in the identity of Russia? Firstly, for Russia the West above all is its neighbor which borders it on land and sea. Since ancient times, there has been considerable interaction of the Slavic peoples with their neighbors, especially the representatives of the Roman-Germanic language community. Secondly, the West is perceived as a distinct socio-political and economic community ("the capitalist world", "the bourgeois world").

Russia in the XIX century and at the end of XX century recognized that the West had achieved considerable success in its economic, social and political development. The EuroAmerican civilization finds its expression in life values, social relations and institutions based on liberal-democratic values. Ideals and conceptual notions of liberal-democratic ideology were laid in ancient culture, and it was the West who brought them to perfection (Batalov E.Y. 2003).

It is important to note that in the modern sense the term "West" is greatly extended. In addition to European countries and the U.S. it includes Canada, Australia and New Zealand.

The West is the personification of "civilization", the "civilized world" that Russia is perceived as the best example of the organization of public and private life. We should note that for many years during the reign of Soviet ideology, our people were inspired the idea of a terrifying character of the capitalist system, inhibiting the freedom and rights of ordinary people. Since the 
late 80 s the mass media has widely popularized the idea that joining the Western world, the entry into being regarded as the immediate historical task of Russia.

\section{Methodology}

In our study we believe that Russia is an independent local civilization. The well-known historian of the last century, A.J. Toynbee defined a civilization as a community of people living in a certain area and having common spiritual traditions and a similar lifestyle. Civilizations can be spread to different countries, and exist for a long time, walking the path from their birth to decline. In the very period there are five civilizations: Western Christian, Orthodox Christian, Islamic, Far Eastern, Hindu (Toynbee A.J. 1996).

Russia is one of the largest countries in the world. Russia lies in Europe and Asia, it is inhabited by various peoples and races, having different religions and a diversity in in social and cultural lifestyles. It is not surprising that since immemorial times Russia has been pictured as a mythical country to the strangers. Its features were very contradictory - "a country full of ice", "a cold country", "a militant country", "a tale country" in which "beautiful and strong" people, on the one hand, and "monstrous, coarse, ignorant" people, on the other hand, live. Thanks to the notes of Western travelers of XV - XIX centuries. (J. Gorsey, S. Herberstein, H. Staden, J. de Stael, etc.), a stable geteorostereotype of Russia as a country of a mystery was formed in the minds of foreigners. In XIX-XX centuries this stereotype was backed with the works of Russian classical writers translated into foreign languages in which some questions about the nature and meaning of human life were answered through the prism of the national identity of the Russian culture (Ten Y.P. 2007).
We should note that literature can not be regarded as the only true and direct source of information about the Russian situation. For example, A.P. Chekhov depicts images of Russian landowners or officials who are largely collective in nature and intended to ridicule in the grotesque form some common human vices and weaknesses.

The modern researcher E.I. Volkova analyzes the allegorical meaning of a smile, and its absence in American and Russian cultures. American smile indicates a country's openness to other people, willingness to accept and absorb them into itself, while Russia throughout its history was forced to repel the attacks of the invaders, closing its borders that symbolically reflected in the fact that the Russian lips are closed and never smile. The openness of the borders of Russia caused a subconscious desire of the people somehow to dissociate themselves from a hostile world, to surround with a kind of the wall - not only militarily but also culturally. It resulted in "repeated attempts to present itself as a center, if not of the world as a whole, but of a some kind of a relatively small community around its borders, such as "Orthodox world", and later "Slavic world", and then "the socialist camp", but the logic of historical development led to a dialogue between cultures... "(BorisovY.S., Golubev V A., Sakharov A.N. 1998)

Perceptions of Russia as something different are focused on the image of the "mysterious Russian soul" in the West. The poetic expression by Tyutchev is widely known - "Russia can not be understood intellectually". Such an attitude to Russia is probably one of the ways to avoid any contact, attempts to create a dialogue and mutual understanding. It is known that the Russian language is very complex in grammar and synthesis, and it is not so easy to learn.

In the light of Euro centrism prevailing over the centuries, Russia does not correspond 
to the standards of the Western civilization as Danilevsky wrote. Russia is an original historical and cultural institution. In crosscultural communication between Russia and the West there are the barriers that impede adequate understanding of the two civilizations. Among the most significant barriers we see: differences in languages, differences in religious traditions of the Christian faith, especially psychology and world view of the two - the West and Russia (Ilyin I. 1992). H. Triandis points out that cultural distance influences the adequacy of convergence of cultures. According to Triandis, “... the negative aspects of diversity are associated with a lower level of cohesion, due to cultural conflicts and differences in cultures" (Triandis G.K. 2007).

In the West's attitude towards Russia there are political considerations and economic calculation. As a result, Russia's image might undergo deliberate distortion. So the perception of Russia abroad, the attitude towards it during the "cold war" was defined by the increase of confrontation of capitalist and socialist camps. At the time of the USSR, the idea of Russia with Western people was complex and ambiguous. Ideological confrontation with the West marked public consciousness. After the collapse of the Soviet Union and the socialist camp extremely complex stereotypes of "the cold war" started in the West and in Russia. The process of establishing new political priorities in the world is controversial and it defines the modern view of the West and Russia against each other in connection with the attempts to balance the global and national interests.

In today's world the range of spheres for intensive interaction between people and countries is being significantly broadened - policy, trade, culture, science, education and tourism. Many people are aware of the necessity to study foreign languages for better communication with foreigners. For example, in Europe it is considered the norm, if a modern educated person knows two or more foreign languages (primarily European ones). There is also a growing interest in studying Japanese and Chinese languages, which is due to expanding business contacts. Unfortunately, the majority of population in Russia does not speak foreign languages fluently. We don't pay much attention to studying languages of neighboring Slavic nations - Ukrainian, Belarusian, etc. Hence, we formulate a scientific and educational aim - to enlarge our knowledge about other peoples' cultures, by identifying, describing and analyzing the specific features of the national image.

The image of the country is a complex, multifaceted phenomenon that must be thoroughly studied, including both the analysis of the image perception of the country by its citizens within the state and the analysis of perception from outside by other nations and civilizations. What we think about foreign countries, their historical and cultural development, national identity, lifestyles of their people are the problems that cause the closest interest in the contemporary humanities. History has put our country in the center of the global, sharply heightened contradictions between countries. In order to counter the negative trends of its development, its development strategy and actions must be based on scientifically based theory, including the formation of the positive self-image.

On the one hand during the Soviet era the Russians formed (due mainly to political propaganda) cautious attitude towards foreign, primarily as a product of capitalist nature. At the same time the Russians were always ready to learn from the West and invited scholars and experts, many of whom stayed to live here, and the Russian culture was proud of their works. Russian people have been always trying to prove to themselves that they are in no way worse than the West. (Hence the popular expression "To 
shoe a flea" or saying "no other view - show yourself").

Russia takes foreign countries ambiguously. Their image in the minds of the Russians is determined not only by an objective place of these countries in the world, their attitude towards Russia and its citizens, but also by common thinking of the Russians about these countries and their people. This thinking is formed in the process of socialization and enculturation, the information received from various sources (radio, television, cinema, Internet, advertising, etc.).

As B. Dubin notes, citing the poll results, the autarky of self-consciousness of the Russians growing in the second half of the 90-s of XX century is accompanied by the fact that the Soviet regime had changed "the nature" of the Russian people that they no longer look like "the western people", and these changes are irreversible, and the sample is unreachable ("the sense of latecomers”). (Dubin, B., 2000:30.)

An American scientist Joseph Nye in his works "Bound to Lead: The Changing Nature of American Power" (1990) and "Soft Power": The Means to Success in World Politics" (2004) distinguishes three components with the help of which the government can have an impact on the foreign policy arena: culture, values and foreign policy itself. America's "Soft power" comes to a large degree not out of state action, but by penetrating into the mass consciousness of American culture, popular brands, ideas of democracy, human rights, globalization and liberal economy. ( Nye, J., 1990, 2004)

The phrase "image making" is getting more and more popular in our life; it means the targeted making of a necessary image of a customer (individual, organizational, state) on the basis of certain stereotypes that make the object highly understandable and important to the party concerned. The effective methods of political image making are being developed to create a visually attractive image, to achieve certain goals - namely, the formation of person's ability to act and think clearly.

The theories of "social exchange" (G. Homans, P. Blau) where human goals (satisfaction or reward) can only be achieved in social interaction, consider the interaction as a constant activity exchange ("benefits" or "values") between people. Everyone, according to G. Homans, seeks to maximize the rewards of their actions and minimize costs. Regular exchange generates the system of mutual expectations; the value-regulatory system plays an important role in the regulation of exchanges.

In recent years the world has entered a sort of a battle not yet of civilizations and states, but of their images. Images often begin to play even a greater role than the "physical force". To create an image of the state we can draw the images visibly expressing the peculiarities of thinking and behavior which a national character is associated with. For example, the UK clearly represents a sensibleand carefulimage of SherlockHolmes. The U.S. is often associated with Uncle Sam. Beauty, courage and freedom of France are expressed by the image of Marianne. To create a national image we can use cultural traditions of everyday life and everyday culture (cuisine, national costume, folklore). For example, in advertising beer festivals in Germany they use the figurines of German girls in national costumes. In terms of reconstruction of the country's national image it is interesting to analyze the epithets traditionally given to different countries. England is often said to be "old and good", Germany - "scientific and educated", France - "beautiful", Spain - "noble", etc. But since ancient times Russia has been considered to be "holy" and "suffering".

The national image of the country in many respects has a collective character and is always multifaceted; it historically depends on relations between states, the geographical location of the 
country, the presence or absence of common interests or, on the contrary, their collision. So for centuries the British and French have not liked each other since the Hundred Years War giving each other offensive nicknames and telling jokes. Things began to change during the Russian Crimean War in the XIX century, a period when France and Britain became allies against Russia.

For most Americans the idea of their own country is based on the concepts of freedom and democracy. The national consciousness includes pride of their own country, superiority, confidence in law and the implementation of democratic principles. In the U.S. to create a positive image is one of the traditional foreign policy priorities. Since September 11, 2001, Washington has intensified their activities in the Islamic world in their attempts to change its international image. China, India, South-East Asia are working upon their international images. A favorable reputation encourages investment and strengthens the position of its leading corporations. In turn, the success of national retail brands contributes the prestige of the state.

There is a standard set of stereotypes about Russia in foreign countries. It includes myths about consumer habits (Russian bath, vodka), some objective characteristics (wide open spaces, cold, Siberia), confidence in its inexhaustible resources. For the West, Russia is associated with a specific set of stories that do not add any attractiveness to the country. Attitude of the elite, mass media, scientists, and ordinary people in the West toward Russia is often opposite. It increases or decreases depending on the events that occur in Russia.

L.S. Ruban says that there has been a paradoxical situation around the image of Russia in the world. The USSR, the empire, has fallen to pieces and Russia turned out to be independent from others and passed into the "Third World countries" de facto. (Ruban, 2002)
According to E.A. Galumov, "the international image of Russia as an economically and politically undeveloped country was largely formed as a result of the information war organized by the USA against the Soviet Union which in fact led to the collapse of the latter ...Today, multi-media separates not a socialist system but the Russian society itself from the civilized world". (Galumov, 2003)

For the ordinary people the perception of someone or something occurs mainly through emotions and their own feelings. On the one hand, this quality makes it easy to "assimilate" someone else's image, but on the other hand, prevents the penetration into the essence of things. "To understand and accept or reject someone else's value system, it is necessary to touch the original sources, to understand the mechanisms of historical stereotypes, the reasons for the change of values", - believes Belgorodskaya. The results of her research are rather interesting. She examines images of the Russians (historical leaders, monarchs, generals, explorers, etc.) in the Anglo-American encyclopedias. Belgorodskaya analyses the image of the prominent historical figures of Russia in the Anglo-American encyclopedias, among them there being Britannica, Americana, Oxford Encyclopedia, dictionaries by A. Palmer, R. Pearce, etc. She concludes that achievements of historical figures at the forefront of world events are very often underestimated. For example, the historical encyclopedia Kingfisher provides information about Napoleon, Nelson, Wellington, but there is not a single word about Kutuzov and Suvorov (Russian outstanding military men). In this case, the mechanism of the so-called thesaurus approach to the knowledge of a foreign culture starts working, when "yours" seems important, essential and fundamental, and "someone else's" looks peripheral, primitive and not worthy of attention. For example, in foreign publications 
trends of development in Russia are estimated only in the western system of goal setting. Key words "Westernization", "modernization" are suggested as the criterion of historical progress. (Belgorodskaya, 2005)

The strengthening of the positive image of Russia is one of the priorities of Russian foreign policy. As E.A. Galumov suggests: "The problem of country's image formation is directly linked to the current system of government and its direct representatives. In the West, the image of Russia is often identified with the image of power. In an era of intense competition among states for spheres of geopolitical and economic and financial impact, foreign media emphasize the negative perceptions of Russia. The image of the state should be synthetic. It must be planned to produce a certain impression with the help of symbols (the heraldic symbols). Country's image should be bright and specific". (Galumov, 2003)

The creation of a positive image of the state belongs to the sphere of public diplomacy which is a set of measures aimed at learning and informing the foreign audience, as well as establishing contacts. This sphere includes public diplomacy journalists writing about this country and foreign nongovernmental organizations. An example of exchange of scientists and young leaders is American Fulbright Program which has been a bridge between the U.S. and the world's intellectual and political elite in recent decades.

According to Russian experts, the image of the New Russia is at the stage of its formation, and therefore did not get a clear perception abroad. It is not easy to accept a new image of post-communist Russia. There is a conflict of transition from one quality to another, social and political transformation. Much is seen through the prism of the "Soviet model". The process of self-knowledge and the process of perception of Russia coincided in time, giving rise to psychological difficulties.
Russia's image formed abroad can be traced in foreign and domestic mass media, the performances of top leaders of states and international organizations. In today's information society it is the media that are an important source of the country's image. They have a strong influence on public opinion; serve both as a source of information and powerful information weapon which is actively used in the information war. And the information policy of the government is the main communicative channel that allows to put into effect political messages, to form an image of government and the state both domestically and abroad.

In the modern era, thanks to the expansion of information channels and means there is an opportunity for the artificial formation of a national image. Certain intellectual elite in the case of socio-economic order can create a series of symbolic texts, embodied in the context of political, social, cultural, religious and other practices. In modern science the concept of "brand image" of the country is becoming more and more popular. This is due to the desire of individual countries to form a positive image of their country through the prism of military, political, economic and industrial, advertising, trade and sociocultural purposes. Unlike the national image of the country, which is formed for decades and sometimes centuries, based on various historical, cultural, and philosophical and political texts, the country's image can be artificially created by media and various kinds of PR-technologies relying on the latest achievements of science and technology (computer technology, Internet development, etc.). In the political-military and the promotional competition some countries tend to portray a negative image of other countries. AsE.A.Galumovsuggests: "Country'simportance and relevance in international relations, in global model of world order, in the system of world civilizations depends on its international image". 
(Galumov, 2003) In the modern world relations between the countries should be developed on the basis of respect for cultural differences, tolerance and desire to the peaceful resolution of global problems of mankind.

In today's society through various technologies the possibilities for forming an artificial image of the state are increasing, and they do not always adequately reflect the real and sometimes artificially distort the true situation in the country.

Hence the problem of purposeful formation of a positive international image of Russia as an equal partner with the state's natural and human resources, the rich historical and cultural traditions occurs.

\section{Conclusion}

So, as the result of our research, we can make a following conclusion. National images of people and nations of each other are perceived ambiguously. National image of the country in many respects has a collective character and is always multifaceted, historically dependent on relations between states, the geographical situation of the country, the presence or absence of common interests or, conversely, their collision. The opinions of other people formed in the process of socialization and enculturation are based on the information received from both the official (radio, television, films, advertising, etc.) and unofficial sources (stories of tourists, anecdotes, rumors, etc.). In today's society through various technologies, the possibilities for forming an artificial image of a state are not always adequately reflects the real and sometimes artificially distort the true situation in that country. Hence the perceived problem of purposeful formation of a positive international image of Russia as an equal partner with the state's natural and human resources, the rich historical and cultural traditions.

\section{References}

1. Batalov E.Ya. Rossiia i Zapad: evoliutsiia Rossiiskogo obshchestvennogo soznaniia. Rossiia mezhdu Vostokom i Zapadom: mosty v budushchee. [Russia and the West: the evolution of Russian public consciousness. Russia between East and West: bridges to the future]. Moscow, 2003, 432 p.

2. Belgorodskaya L.V. Obrazy russkikh v Anglo-Amerikanskikh Entsiklopediiakh. [Images of the Russians in English-American encyclopedias]. Teaching History at schools. №4, 2005. P. 66.

3. Borisov Y.S., Golubev A., Sskharov A.N. Istoriia. Rossiia i Zapad. Obraz Rossii v mirovoi kul'ture i obrazy drugikh stran v rossiiskoi kul'ture XIX-XX vekov. [The history. Russia and East. The image of Russia in world culture and images of other countries in the Russian culture XIX-XX centuries]. Moscow, 1998, P. 22.

4. Galumov E.A. Mezhdunarodnyi obraz Rossii: strategii formirovaniia. [International image of Russia: strategies of forming]. Moscow, 2003.

5. Dubin B. Zapad, granitsa, osobyi obraz: simvoly "chuzhogo" v politicheskoi mifologii v sovremennoi Rossii. [The West, border, specific way: symbols of "someone's" in political mythology in modern Russia]. Monitoring of public opinion. №6 (50) November - December. 2000. P. 30.

6. Erygin A.N. Istorichskaia tipologiia kultur. [Historical typology of cultures]. Culture. Rostov on Don, 1998. P. 127.

7. Ilyin I. Nasha zadacha. [Our task]. Moscow, 1992.

8. Nye J. Bound to Lead: The Changing Nature of American Power, 1990.

9. Nye J. "Soft Power": The Means to Success in World Politics, 2004. 
10. Kononenko V. Sozdat' obraz Rossii? [To create the image of Russia?] Russia in the global policy. T. 4. №2, 2006, 196 p.

11. Koval B.I., Dyakova L.V. Latinskaia Amerika smotrit s udivleniem na Rossiiu. [Latin America is looking with surprise at Russia. Latin America]. №12, 2006. P. 5.

12. Ruban L.S. Evoliutsiia fenomena "Sil'noe gosudarstvo". Sistemy kollektivnoi bezopastnosti i sovremennyi mir. [The evolution of the phenomenon "Powerful State". Systems of collective security and the modern world]. Information. Diplomacy. Psychology. M., 2002.

13. Ten Y.P. Kul'turnye issledovaniia i mezhkul'turnaia kommunikatsiia. [Cultural Studies and Intercultural Communication]. Rostov on Don, 2007. P. 254.

14. Toynbee A.J. Tsivilizatsiia pered litsom istorii. [Civilization in the face of history]. Moscow, 1996.

15. Triandis G.K. Kul'tura i sotsial'noe povedenie. [Culture and social behavior]. Moscow, 2007, $294 \mathrm{p}$.

\title{
Национальные образы стран
}

\section{в межкультурном взаимодействии мировых цивилизаций в современный период}

\author{
И. Борисенко, Г. Григорьева \\ Южно-Российский государственный университет \\ экономики и сервиса \\ Россия, 346500, Шахты, Ростовская обл., Шевченко, 147
}

Становление национального самосознания обусловлено процессом сравнения «себя» $c$ «другим». Ощущение национальной идентичности - это фиксаџия различия «свои - чужие», «наши - не наши». Когда формируется сама этническая культура, тогда происходит интенсивный процесс самоосмысления, самоидентификации, складывается «образ себя» 6 соотнесении с «образами» других народов, стран и культур.

Для человеческого сознания с древних времен свойственно особое отношение к проблеме формирования образа своего народа и образов других народов. Данная статья посвящена анализу этой проблемы. В ней рассматриваются начиональные образы стран в системе межкультурного взаимодействия мировых иивилизаций в современный период. Выявлено, что высокая степень различия культур и особенности религиозных традиций, вековые политические разногласия и военные конфликты между Западом и Россией способствовали формированию различного рода барьеров, которые мешают достижению адекватного взаимовосприятия и взаимопонимания двух ичивилизаиий. В современный период для более полного и ясного взаимопостижения национальных образов актуализируется проблема преодоления различного рода коммуникачионных барьеров в общении Запада и России. При этом основными инструментами формирования «национального образа» выступают реклама и паблик-рилейшенз.

Ключевые слова: национальный образ, межкультурное взаимодействие, создание образа.

Научная специальность: 24.00.00 - культурология, 09.00.00 - философские науки. 